\begin{tabular}{l}
\hline MATAPPA: Jurnal Pengabdian Kepada Masyarakat \\
Volume 2 | Nomor 2| Maret |2019 \\
e-ISSN: 2614-6673 dan p-ISSN: $2615-5273$ \\
\begin{tabular}{|l|l|} 
(c) (1) This work is licensed under a Creative Commons Attribution \\
\hline
\end{tabular}
\end{tabular}

\title{
Pembinaan Karakter Melalui Kegiatan Membaca Kritis Pada Siswa SMP Kota Bekasi
}

\section{Aster Pujaning Ati ${ }^{1}$, Sigit Widiyarto ${ }^{2}$}

\begin{tabular}{l}
\hline \hline Keywords: \\
Pembinaan; \\
Karakter; \\
Membaca Kritis \\
\\
Corespondensi Author \\
Bahasa Indonesia \\
${ }^{1}$ Universitas Indraprasta PGRI \\
Jakarta \\
Email: \\
asterpujaningati@ ymail.com
\end{tabular}

History Artikel

Received: 24 Jan 2019

Reviewed: 10 -02-2019

Revised: 28-02-2019

Accepted:27-03-2019

Published: 27-03-2019

\begin{abstract}
Abstrak. Pembelajaran karakter sangat penting guna penanam budi pekerti yang sopan dan santun. Pembelajaran penanaman karakter pada siswa sering terlupakan, dan perlu digalakkan guna membekali siswa di era industry 4.0 yang penuh dengan kompetisi lokal dan global. Tujuan kegiatan ini untuk memberikan pemahaman yang baik tentang suatu bacaan bermutu dan baik, sehingga siswa diharapkan mampu mengubah pola pikir dan karakter mereka. Metode yang digunakan meliputi metode partisipatif, simulasi dan pendampingan serta pembiasaan. Hasil kegiatan ini menunjukkan bahwa, siswa sudah dapat memilah buku bacaan yang berkualitas baik dalam hal budi pekerti maupun karakter yang baik, dan mereka dapat mengaplikasikan karakter dengan baik di sekolah.
\end{abstract}

\begin{abstract}
Character learning is very important for cultivating polite and polite people. Learning to plant character in students is often forgotten, and needs to be encouraged to equip students in the industrial era 4.0 which is full of local and global competition. The purpose of this activity is to provide a good understanding of quality and good reading, so that students are expected to be able to change their mindset and character. The method used includes participatory methods, simulations and mentoring as well as habituation. The results of this activity indicate that students have been able to sort reading books that are of good quality in terms of character and good character, and they can apply the characters well in school
\end{abstract}

PENDAHULUAN
Pada hakikatnya, pembelajaran bahasa
adalah belajar berkomunikasi,
merupakan sarana komunikasi dalam
masyarakat yang dilakukan dalam kehidupan
sehari-hari. Untuk dapat berkomunikasi dengan
baik, seseorang perlu belajar cara berbahasa
yang baik dan benar. Pembelajaran tersebut akan
lebih baik manakala dipelajari sejak dini dan
berkesinambungan. Oleh karena itu,

pembelajaran bahasa disertakan dalam kurikulum, hal ini berarti setiap peserta didik dituntut untuk mampu menguasai bahasa yang mereka pelajari terutama bahasa resmi yang dipakai oleh negara yang di tempati peserta didik. Begitu pula di Indonesia, bahasa Indonesia menjadi materi pembelajaran yang wajib diberikan di setiap jenjang pendidikan, mulai dari sekolah dasar sampai perguruan tinggi. Hal itu dilakukan agar peserta didik 


\section{MATAPPA: Jurnal Pengabdian Kepada Masyarakat.}

mampu menguasai bahasa Indonesia dengan baik dan benar serta mampu menerapkannya dalam kehidupan masyarakat.

Pengajaran bahasa Indonesia terdiri dari beberapa aspek kemampuan berbahasa dan bersastra. Kemampuan berbahasa dan bersastra meliputi empat aspek keterampilan, yaitu keterampilan membaca, membaca, menyimak, dan berbicara, salah satu dari keempat keterampilan itu yakni keterampilan membaca. Keterampilan membaca tidak dapat diperoleh secara alamiah, tetapi melalui proses belajar mengajar. Membaca merupakan kegiatan yang bersifat berkelanjutan sehingga pembelajarannya pun perlu dilakukan secara berkesinambungan sejak sekolah dasar. Hal ini didasarkan pada pemikiran bahwa membaca merupakan kemampuan dasar sebagai bekal belajar membaca dijenjang berikutnya. Oleh karena itu, pembelajaran membaca di sekolah perlu mendapat perhatian yang optimal sehingga dapat memenuhi target kemampuan membaca yang diharapkan. Membaca sebagai suatu kegiatan berbahasa yang bersifat aktif dan produktif merupakan kemampuan yang menuntut adanya kegiatan encoding yaitu kegiatan untuk menghasilkan atau menyampaikan bahasa kepada pihak lain melalui tulisan.

Pengajaran Bahasa Indonesia terdiri dari aspek kemampuan berbahasa dan bersastra .Kemampuan berbahasa dan bersastra meliputi empat aspek keterampilan.Salah satunya adalah keterampilan membaca .Keterampilan tersebut sangat penting dalam kehidupan. Dengan membaca, seseorang dapat menceritakan ide, perasaan, peristiwa, dan benda kepada orang lain. Oleh karena itu, kemampuan ini perlu diajarkan di sekolah dasar dengan tepat.Selain itu membaca juga merupakan salah satu dari ketrampilan berbahasa yang harus dikuasai dengan baik oleh siswa.Dengan membaca dapat melatih kita untuk berpikir kritis dan logis.Serta dapat mengungkapkan perasaan ide, gagasan atau melukiskan lambang-lambang grafik yang menggambarkan suatu bahasa yang dipahami oleh seseorang, sehingga orang-orang lain dapat membaca lambang-lambang grafik tersebut kalau mereka memahami bahasa dan grafik itu.gambar atau lukisan mungkin dapat menyampaikan makna-makna, tetapi tidak menggambarkan kesatuan-kesatuan bahasa.

Membaca merupakan media untuk berkomunikasi seseorang kepada orang lain. Pada hakikatnya, pembelajaran bahasa adalah belajar berkomunikasi, bahasa merupakan sarana komunikasi dalam masyarakat yang dilakukan dalam kehidupan sehari-hari. Untuk dapat berkomunikasi dengan baik, seseorang perlu belajar cara berbahasa yang baik dan benar. Pembelajaran tersebut akan lebih baik manakala dipelajari sejak dini dan berkesinambungan. Oleh karena itu, pembelajaran bahasa disertakan dalam kurikulum, hal ini berarti setiap peserta didik dituntut untuk mampu menguasai bahasa yang mereka pelajari terutama bahasa resmi yang dipakai oleh negara yang di tempati peserta didik. Begitu pula di Indonesia, bahasaIndonesia menjadi materi pembelajaran yang wajib diberikan di setiap jenjang pendidikan, mulai dari sekolah dasar sampai perguruan tinggi. Hal itu dilakukan agar peserta didik mampu menguasai bahasa Indonesia dengan baik dan benar serta mampu menerapkannya dalam kehidupan masyarakat.

Pengajaran bahasa Indonesia terdiri dari beberapa aspek kemampuan berbahasa dan bersastra.Kemampuan berbahasa dan bersastra meliputi empat aspek keterampilan, yaitu keterampilan membaca, membaca, menyimak, dan berbicara, salah satu dari keempat keterampilan itu yakni keterampilan membaca. Keterampilan membaca tidak dapat diperoleh secara alamiah, tetapi melalui proses belajar mengajar. Membaca merupakan kegiatan yang bersifat berkelanjutan sehingga pembelajarannya pun perlu dilakukan secara berkesinambungan sejak sekolah dasar. Hal ini didasarkan pada pemikiran bahwa membaca merupakan kemampuan dasar sebagai bekal belajar membaca dijenjang berikutnya. Oleh karena itu, pembelajaran membaca di sekolah perlu mendapat perhatian yang optimal sehingga dapat memenuhi target kemampuan membaca yang diharapkan. Membaca sebagai suatu kegiatan berbahasa yang bersifat aktif dan produktif merupakan kemampuan yang menuntut adanya kegiatan encoding yaitu kegiatan untuk menghasilkan atau menyampaikan bahasa kepada pihak lain melalui tulisan. Maka dari itu, penggunaan metode sangat penting kehadirannya dalam pelajaran.Namun kegiatan belajar mengajar yang disertai dengan penggunaan metode pembelajaran sangat tepat untuk meningkatkan prestasi belajar siswa. Selain itu cara mengajar guru harus menggunakan teknik pembelajaran yang bervariasi secara kreatif.

Beberapa permasalahan yang sering dihadapi oleh siswa-siswi di Mts Nurul Hikmah 
diantaranya ,siswa belum bisa menyeleksi bacaaan yang bermutu dan baik. Kemampuan membaca kritis yang masih rendah.

Tujuan dari kegiatan pengabdian masyarakat ini adalah ,1)memberikan manfaat bagi siswa di Mts Nurul Hikmah dan Attaqwa dalam proses belajar mengajar khususnya membaca kritis, 2) untuk meningkatkan kualitas karakter dan pembelajaran membaca buku yang bagi siswa, 3) untuk meningkatkan kemampuan membaca kritis siswa.

\section{METODE}

Pada pelaksanaan kegiatan pengabdian masyarakat, tim pelaksana mempunyai pertimbangan khusus untuk memilih sekolah yang akan diberikan penyuluhan dan penanaman karakter. Tim berkoordinasi dengan beberapa kepala sekolah di kota Bekasi dan bertemu dengan kepala dinas setempat. Dari hasil pertemuan ,tim memutuskan untuk melaksanakan di 2 sekolah menengah lanjut. Kedua sekolah itu adalah Mts Nurul Hikmah dan SMP Attaqwa Kota Bekasi. Pelaksanaan dibagi dua tahap. Tahap pertama dilakukan di Mts Nurul Hikmah dan tahap kedua di SMP attaqwa yang berlokasi di Kecamatan Babelan kabupaten Bekasi. Jumlah siswa yang ikut sebanyak 51 siswa Mts Nurul Hikmah dan 61 siswa SMP Attaqwa. Metode yang digunakan meliputi metode yang partisipatif, simulasi dan pendampingan serta pembiasaan.

\section{HASIL DAN PEMBAHASAN}

Pelaksanaan kegiatan berlangsung mulai bulan Maret 2018. Pertemuan awal tim abdimas memperkenalkan diri .Para siswa juga diberi penjelasan pentingnya pelajaran bahasa Indonesia,dan manfaat membaca kritis. Para siswa dipersilahkan bertanya. Siswa ada bertanya tentang membaca dan jenisnya. Pertemuan berikutnya selama 45 x 2 membahas tentang membaca krits. Pada pertemuan ini anak dilatih membaca kritis. Para siswa antusias untuk mengikuti kegiatan tersebut. Pertemuan berikutnya siswa diberi materi/teks dengan membaca secara kritis. Pada pertemuan keempat, diadakan evaluasi para fasilitator mengulang kembali,dengan Metode ini diajarkan membaca kritis.

Adapun buku yang menjadi bahan bacaan siswa ada beberapa pilihan tema dan topik.
Buku yang menjadi bacaan seperti :

1.Jaka dan Naga Sakti -Badan

Pengembangan bahasa,Kemendikbud 2016

2.Raja Madura yang perkasa dan Bijaksana

Badan Pengembangan bahasa,Kemendikbud

2017

3.Si cantik dan sang Pemberani.

Badan pengembangan bahasa,Kemendikbud 2017. Adapun 4 teknik dalam membaca kritis sebagai berikut :

Tabel.1. Kemampuan dan Nilai

\begin{tabular}{lll}
\hline No & \multicolumn{1}{c}{$\begin{array}{c}\text { Kemampuan yang } \\
\text { dikembangkan }\end{array}$} & $\begin{array}{c}\text { Keterangan } \\
\text { Pemberian } \\
\text { nilai }\end{array}$ \\
\hline 1 & Mengerti isi bacaan & $1-10$ \\
2 & Menguji sumber penulis & $1-10$ \\
3 & Menganalisa isi bacaan & $1-10$ \\
4 & Terbuka terhadap & $1-10$ \\
& gagasan penulis & \\
\hline
\end{tabular}

Tabel.1. Kemampuan membaca kritis

Para siswa diberikan waktu selama 2 hari untuk membaca sebanyak 2 buku . Isi buku penuh dengan hikmah pelajaran dan karakter yang baik.

Setelah itu tim memberikan pertanyaan tertulis mengenai isi,hikmah dan karakter yang terkandung dalam buku.

Hasil yang didapat sebagai berikut :

Tabel. 2. Kegiatan sebelum dan sesudah

\begin{tabular}{|c|c|c|}
\hline Kemampuan & $\begin{array}{l}\text { sebelum } \\
\text { kegiatan }\end{array}$ & $\begin{array}{c}\text { Setelah } \\
\text { Kegiatan }\end{array}$ \\
\hline $\begin{array}{l}\text { Mengerti isi } \\
\text { bacaan }\end{array}$ & 63 & 72 \\
\hline $\begin{array}{l}\text { Menguji sumber } \\
\text { penulis }\end{array}$ & 53 & 65 \\
\hline $\begin{array}{l}\text { Menganalisa isi } \\
\text { bacaan } \\
\text { Terbuka } \\
\text { terhadap }\end{array}$ & 56 & 60 \\
\hline gagasan penulis & 56 & 59 \\
\hline
\end{tabular}

Tabel 3. Diagram batang kegiatan

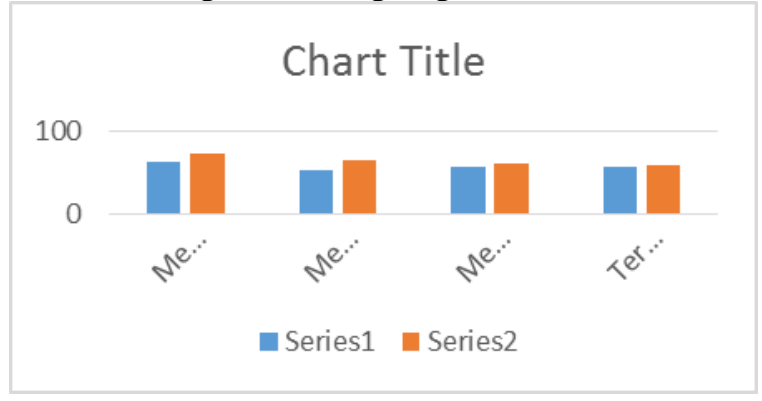

Diagram. 3. Grapik peningkatan Nilai kemampuan membaca kritis 


\section{MATAPPA: Jurnal Pengabdian Kepada Masyarakat.}

Menjelaskan tentang hasil atau luaran pengabdian bisa berupa peningkatan pengetahuan, keterampilan atau berupa produk. Hasil juga mengemukakan tingkat ketercapaian target kegiatan. Jika berupa benda perlu ada penjelasan spresifikasi produk, keunggulan dan kelemahannya. Penulisan luaran perlu

dilengkapi foto, tabel, grafik, bagan, gambar dsb. Pembahasan berurut sesuai dengan urutan dalam tujuan, dan sudah dijelaskan terlebih dahulu. Pembahasan disertai argumentasi yang logis dengan mengaitkan hasil $\mathrm{PkM}$ dengan teori, hasil PkM yang lain dan atau hasil penelitian.
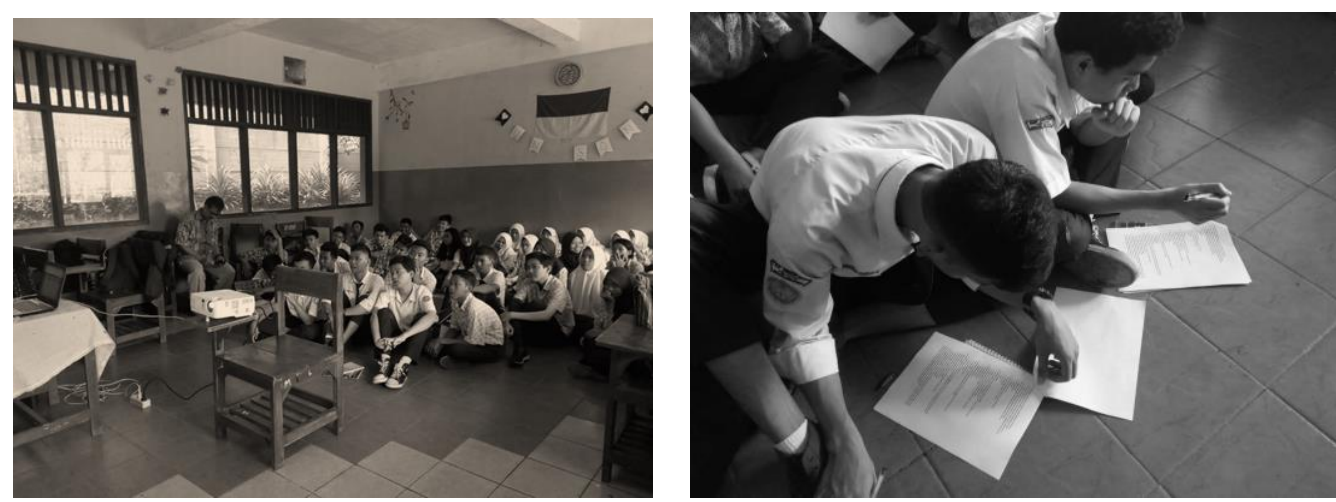

Gambar .1 dan 2 .Kegiatan Pengabdian Masyarakat pada Mts Nurul Hikmah dan SMP Attaqwa.

Setelah siswa mengikuti serangkaian kegiatan ,maka siswa mengaplikasi karakter yang ada didalam buku dengan cara simulasi (mementaskan dalam bentuk drama),peran dan partisipasi guru dan orang tua dirumah diajak dengan menonton dan mendukung karakter yang baik seperti rajin ,pemberani, membela yang benar dan sebagainya. Diharapkan kegiatan ini dapat dimonitor dan orang tua ikut mendampingi siswa dirumah. Bagi guru dapat mendampingi disekolah,dengan membuat drama dari cerita dibuku,serta memantau perilaku siswa disekolah

\section{SIMPULAN DAN SARAN}

Kegiatan pengabdiaan masyarakat yang dilakukan ini sangat perlu dan dirasakan manfaat bagi peningkatan proses belajar mengajar di sekolah. Kegiatan ini juga memberikan kontibusi yang positif untuk menciptakan pembelajaran yang optimal. Kegiatan ini telah berjalan dengan baik dan dapat disimpulkan sebagai berikut : (1) Siswasiswi menjadi lebih termotivasi, dan memiliki ide dan gagasan dalam menanggapi suatu informasi; (2) Siswa lebih kritis dalam menyerap sebuah informasi,sehingga dapat memilah informasi yang fakta atau mitos.

Dari simpulan di atas, kami mengajukan sebagai berikut : 1)siswa hendaknya diberi arahan dalam menyerap informasi yang didapatkan, 2) siswa diharapkan lebih kritis dalam mendapatkan sebuah dinformasi, 2) kerjasama yang baik dan berkesinambungan perlu dilakukan antarlembaga sekolah, baik kepala sekolah, guru, pengawas, orang tua dan siswa-siswi

\section{DAFTAR RUJUKAN}

Lickona, Thomas. (1991). Educating for Character: How Our School Can Teach. Respect and

Responsibility. New York, Toronto, London, Sydney,. Aucland:

Elfindri, dkk, (2010), Soft Skill untuk Pendidik , Praninta Offset,Baduose Media

Widiyarto, S. (2017). Peranan Soft Skill dan Minat Baca Terhadap Kemampuan Menulis Eksposisi Mata Pelajaran Bahasa Indonesia. Semantik, 6(2), 31-38. 